\title{
Characterization of saline dust emission resulted from Urmia Lake drying
}

\author{
Akbar Gholampour ${ }^{1,2}$, Ramin Nabizadeh', Mohammad Sadegh Hassanvand ', Hasan Taghipour ${ }^{1}$ \\ Shahrokh Nazmara ${ }^{3}$ and Amir Hossein Mahvi $i^{3,4,5^{*}}$
}

\begin{abstract}
Compared with common dust storms, saline dust storms transport high concentrations of fine-grain saline and alkaline material. The saline dust storm differs from common dust storm, especially considering the sources of the suspended particulate matter (PM), chemical composition, grain size, and circulation processes. Atmospheric particulate matters (TSP, $\mathrm{PM}_{10}, \mathrm{PM}_{2.5}$, and $\mathrm{PM}_{1}$ ) and their water-soluble ions were concurrently measured at two sites located at north and southeast part of Urmia lake from January 2013 to September 2013. Particulate matters (PMs) were measured using high volume sampler and HAZ-DUST EPAM-5000 particulate air monitors. In both of the sampling sites, the highest concentration of PM was observed during the summer season (521.6, 329.1, 42.6, and 36.5 for TSP, $\mathrm{PM}_{10}, \mathrm{PM}_{2.5}$, and $\mathrm{PM}_{1}$, respectively). A total of 11 inorganic water-soluble ions in the TSP and $\mathrm{PM}_{10}$ were identified by ion chromatography (IC). No statistically significant difference was found between PM's ions concentrations of two sampling sites. The average of the total measured water-soluble ions in the sampling sites was $28.75 \pm 12.9 \mu \mathrm{g} / \mathrm{m}^{3}$ (11.9 $\pm 4.8 \%$ of total TSP mass) for TSP and $14.65 \pm 7.1 \mu \mathrm{g} / \mathrm{m}^{3}$ (8.7 \pm 4.4 of total PM 10 mass) for $\mathrm{PM}_{10}$. Among all detected ions, sulfate was the dominant constituent followed by nitrate and sodium. This study showed that the water soluble salts compose 3-20\% of the total mass of TSP and PM10. The PCA analysis showed that saline particulates formed from Urmia lake bed were the dominant source (57.6\%) of TSP. In addition, saline particulates together with crustal materials resulted from resuspension were the main source (59.9\%) of PM 10 .
\end{abstract}

Keywords: Urmia Lake, Saline dust, Particulate matters, Water-soluble ions, Source identification, lons correlation

\section{Background}

Dust Storm phenomenon could change global climate and affect the economy and quality of human life [1]. In addition to contribution of the formation of gypcrete and calcrete, dust may lead to accumulation of more water soluble salts in soil profiles and thus contribute to salinization [2]. The saline dust storm differs from common dust storm, especially considering the sources of the suspended particulate matter (PM), chemical composition, grain size, and circulation processes. Saline dust storms are defined as "a kind of environmental disaster phenomenon in arid and semiarid regions that has been caused by dust deflated from the salt-rich sediments of dried lake beds and strongly salinized soils on

\footnotetext{
* Correspondence: ahmahvi@yahoo.com

${ }^{3}$ School of Public Health, Tehran University of Medical Sciences, Tehran, Iran

${ }^{4}$ Center for Solid Waste Research, Institute for Environmental Research,

Tehran University of Medical Sciences, Tehran, Iran

Full list of author information is available at the end of the article
}

the margins of lake floors" [3, 4]. Such a phenomena has been registered in many parts of the world, including the Aral Sea region in Kazakhstan and Uzbekistan, Lake Balkhash region in Kazakhstan, the Inner Mongolian region of China, southeastern Australia, and many other regions with arid and semiarid climate [5]. It was cleared that due to salt accumulation, sparse or absent of vegetation, and easily occurrences of wind erosion, these surface sediments will form a sleazy texture [3].

Compared with common dust storms, saline dust storms transport high concentrations of fine-grain saline and alkaline material, such as sodium sulfate, sodium chloride, and other potentially toxic components which could be threaten to the ecological security and humans health in the arid regions $[3,6,7]$.

As mentioned above, chemical composition of saline dust storms is concerned to the characterization of region soil properties, and this redistribution leads to dual effects depending on the nature of transported 
material. Based on studies, saline dust storms are rich in $\mathrm{CaCl}_{2}, \mathrm{NaCl}, \mathrm{MgCl}_{2}$ and other chloride particles, which can be suspended in the atmosphere for long periods of time [8].

Urmia lake, located in northwest of Iran, is the second great saline lake in the world and the largest lake in Iran. In recent decade, the water level at Urmia lake has fallen more than 5 meters and the concentration of salt in this lake has increased from 185 to $220 \mathrm{~g} / \mathrm{L}$ [9]. In addition to decrease in water level and increase in salt concentration, the unique ecosystem of the lake is being destroyed. As a result, a salt desert would be created with an area of more than $5000 \mathrm{~km}^{2}$ (Fig. 1), overlaid with a 50-60 cm thick salt deposits [10]. In the warm season, wind could carry out these salts and transport those to adjacent areas as far as $300 \mathrm{~km}$. The transported PM could damage agricultural lands, pollute the ecosystem and cause variety of diseases in nearby urban and rural areas [9].

Hitherto, no study has been conducted about atmospheric PM in Urmia Lake bed. The present study was therefore carried out to determine the mass levels of total suspended particulate (TSP), $\mathrm{PM}_{10}, \mathrm{PM}_{2.5}$ and $\mathrm{PM}_{1}$ (aerodynamic diameter smaller than $10,2.5$ and $1 \mu \mathrm{m}$, respectively) along with the variations of water-soluble ionic species associated with TSP and $\mathrm{PM}_{10}$ in the floor of Urmia Lake.

\section{Methods}

Study area, sampling sites and schedule

Based on the region wind direction, two sites were selected (Fig. 2); 1) Tasuj site, located in the north of Urmia lake

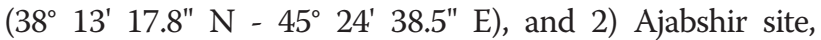
located in the southeast of Urmia lake (37 $31^{\prime} 12.9^{\prime \prime} \mathrm{N}-45^{\circ}$ 47' 53.0" E). The level of TSP, $\mathrm{PM}_{10}, \mathrm{PM}_{2.5}$ and $\mathrm{PM}_{1.0}$ were measured 8 times every season in the period of January 2013 to September 2013. In total, 48 samples of TSP and $\mathrm{PM}_{10}$ were collected and analyzed during the study period.

\section{PMs measurement}

TSP and $\mathrm{PM}_{10}$ samples were collected by two high volume samplers manufactured by Graseby-Andersen at flow rates of $1.13-1.41 \mathrm{~m}^{3} / \mathrm{min}$ for $24 \mathrm{~h}$. Both TSP and $\mathrm{PM}_{10}$ were collected on a $20.3 \mathrm{~cm} \times 25.4 \mathrm{~cm}$ Whatman glass micro fiber filter. Before and after sampling, filters were set under $40 \%$ relative humidity $(\mathrm{RH})$ at $25^{\circ} \mathrm{C}$ for over $48 \mathrm{~h}$, afterward at room condition for $2 \mathrm{~h}$; then were weighed three times using an $A \& D$ electronic balance with the reading precision of $0.1 \mathrm{mg}$. $\mathrm{PM}_{2.5}$ and $\mathrm{PM}_{1.0}$ were measured using two portable HAZ-DUST EPAM-5000 particulate air monitors.

\section{Chemical analysis}

For water soluble ions analysis, one quarter of each filter was placed in a glass vial and then $40 \mathrm{~mL}$ ultra pure water (specific resistance $\geq 18 \Omega \mathrm{cm}$ ) was added. The vials were
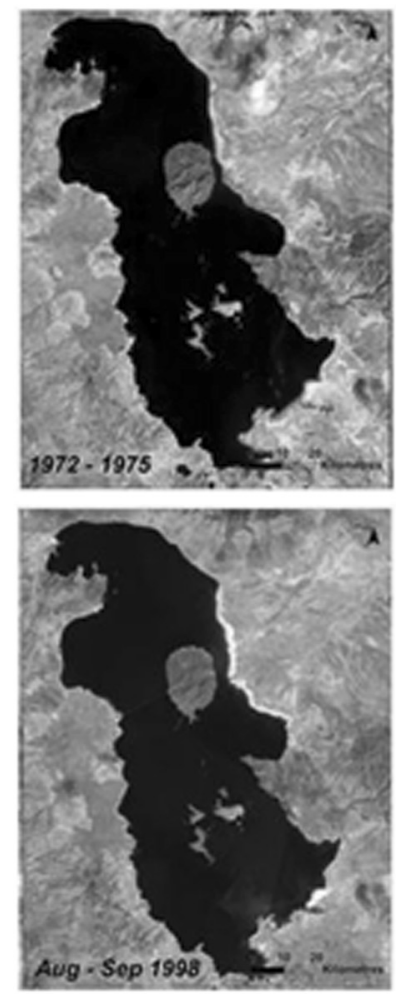
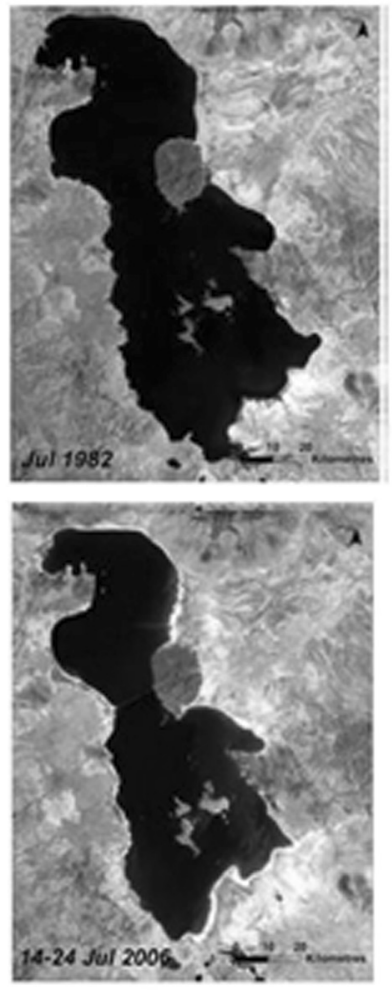
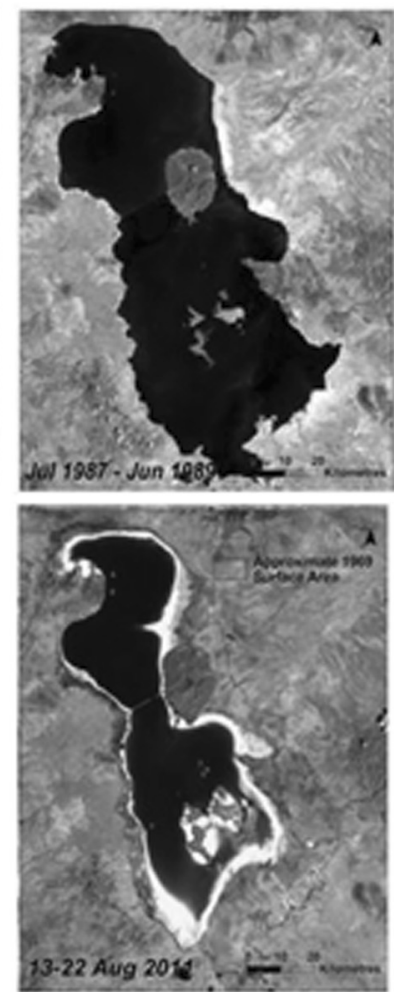

Fig. 1 Decreasing area of Urmia Lake since 1972 to 2011 shown in LANDSAT images (Pengra, 2012) 


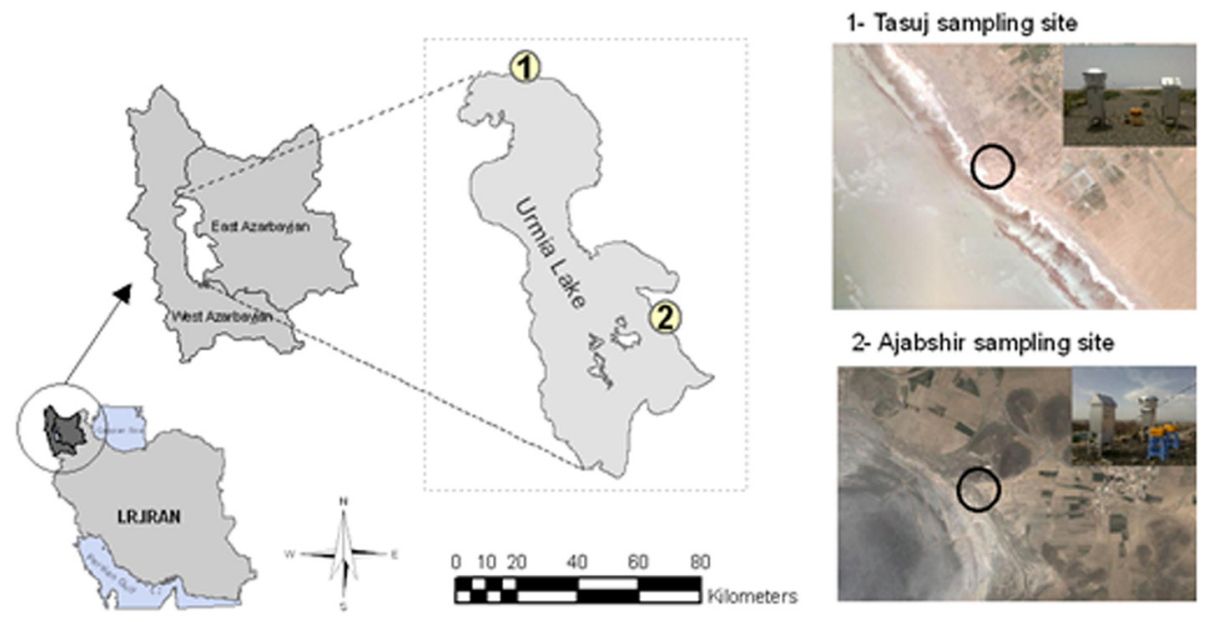

Fig. 2 Location of study area and sampling sites

shaken for $2 \mathrm{~h}$, and subsequently were ultra-sonicated for 30min. The extracted solutions were filtered through a micro porous membrane (with the pore size $0.45 \mu \mathrm{m}$ ) [11]. An ion chromatograph (Metrohm 850 Professional IC, Switzerland) with operating flow rate of $0.7 \mathrm{~mL} / \mathrm{min}$ was used to analyze water-soluble ions. Field and laboratory blanks and spiked samples were analyzed along with the PM samples. For all ions, method detection limits (MDLs) were calculated by adding three standard deviations of the blank readings to the average of five replicates of the blank. The obtained MDLs and the recovery efficiencies for water-soluble ions are presented in Table 1.

\section{Size and morphology}

To determine the morphology and the elemental composition of the collected particles, TSP and $\mathrm{PM}_{10}$ samples were analyzed separately using the SEM-EDX system at the Razi Metallurgical Research Center.

\section{Data analysis}

Data were analyzed (with SPSS20 statistical software, SPSS Inc.) by means of the linear regression (for correlation coefficients among water-soluble ions), the bivariate correlations (to quantify the relation between the elemental concentrations), dimension reduction factor (for the quality principal components (PCs) of TSP and $\mathrm{PM}_{10}$ ), and multivariate test (to quantify significance different between ions concentrations in Tasuj site vs.
Ajabshir site). Differences and correlations were considered significant at the 0.05 level.

Meteorological data were obtained from the national climatic data center [12] and East Azerbaijan Meteorological Organization. The obtained data were examined for the missing values and outliers, and then were entered into WRPLOT View Freeware 7.0.0 to plot the wind-rose. The concentrations of PM were analyzed using Microsoft Excel 2010.

\section{Results and discussion Meteorological dates}

Based on the collected meteorological dates, in both sampling sites, February was the coldest month with the monthly mean temperature of $-1.0^{\circ} \mathrm{C}$, while August was the warmest month with the mean temperature of $28.0^{\circ}$ C. Also the RH varied from 25 to $72 \%$. Dates of wind speed and the direction in both sampling sites revealed that in Ajabshir township, seasonal mean wind speed were $2.8,2.72,2.48$ and $2.12 \mathrm{~m} / \mathrm{s}$, while in the Tasuj township were $2.36,3.28,3.25$ and $1.97 \mathrm{~m} / \mathrm{s}$ in winter, spring, summer and autumn, respectively. Annual wind rose plots for both sampling sites are shown in Fig. 3.

In Tasuj Township, the annual prevailing wind blew from South and South West with the speed of $0.5-13.6 \mathrm{~m} / \mathrm{s}$. The annual mean wind speed was $2.57 \mathrm{~m} / \mathrm{s}$. Calm wind $(0 \mathrm{~m} / \mathrm{s})$ frequencies were $0.13,0.6,1.0$, and $2.24 \%$ in spring, summer, autumn and winter, respectively. In Ajabshir

Table 1 MDLs and recovery efficiencies for water- soluble ions

\begin{tabular}{|c|c|c|c|c|c|c|c|c|c|c|c|}
\hline Water-soluble ion & $\mathrm{Na}^{+}$ & $\mathrm{NH}_{4}^{+}$ & $K^{+}$ & $\mathrm{Mg}^{2+}$ & $\mathrm{Ca}^{2+}$ & $F^{-}$ & $\mathrm{Cl}^{-}$ & $\mathrm{NO}_{2}^{-}$ & $\mathrm{NO}_{3}^{-}$ & $\mathrm{SO}_{4}^{2-}$ & $\mathrm{PO}_{4}^{2-}$ \\
\hline$\overline{M D L s}(\mathrm{ng} / \mathrm{mL})$ & 95 & 6.3 & 4.4 & 12.5 & 5.3 & 3.7 & 6.5 & 3.6 & 52 & 45 & 6.1 \\
\hline $\operatorname{MDLs}{ }^{a}\left(\mu \mathrm{g} / \mathrm{m}^{3}\right)$ & 0.0025 & 0.0002 & 0.0001 & 0.0003 & 0.0001 & 0.0001 & 0.0002 & 0.0001 & 0.0014 & 0.0012 & 0.0002 \\
\hline Recovery efficiencies (\%) & $97-103$ & $78-106$ & $101-103$ & $112-133$ & $109-122$ & $105-107$ & $99-103$ & $100-117$ & $98-104$ & $102-104$ & $95-106$ \\
\hline
\end{tabular}




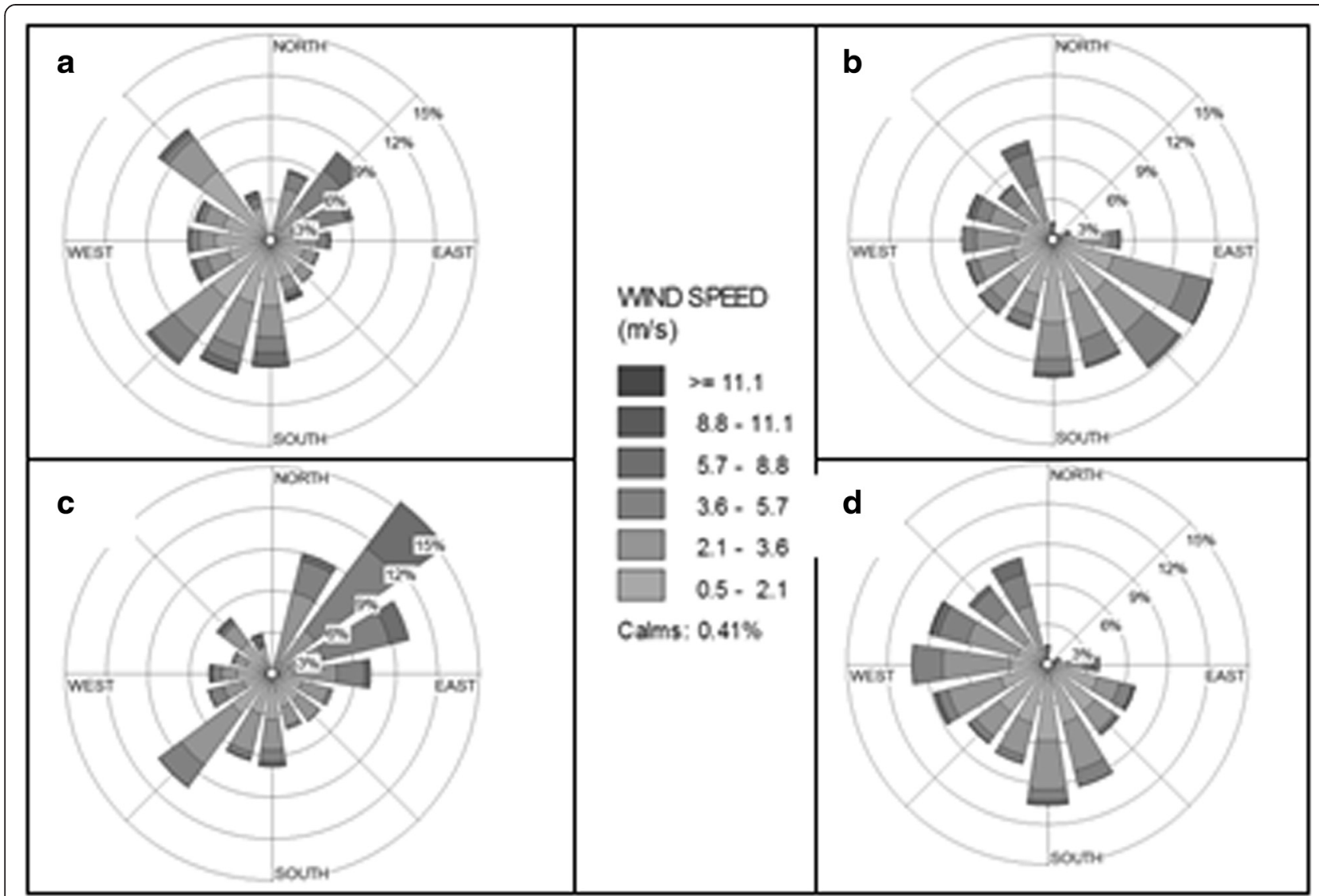

Fig. 3 Annual wind rose plots during the year of 2012 for (a) Tasuj and (b) Ajabshir and wind rose plots during June to January for (c) Tasuj and (d) Aajabshir

Township, wind speed varied from 0.5 to $11.12 \mathrm{~m} / \mathrm{s}$ and annual mean wind speed was $2.57 \mathrm{~m} / \mathrm{s}$. In this region the annual prevailing wind blew from South and South East. Also, calm wind $(0 \mathrm{~m} / \mathrm{s})$ frequencies were $0.5,0.5,2.9$, and $1.0 \%$ in spring, summer, autumn and winter, respectively.

It was cleared that a drought associated with strong wind is regarded as the climatic background for the formation of dust storms [13, 14]. With respect to meteorological dates, June to September have the greatest potential to create dust storm, therefore, in order to predict the direction of probable saline dust storm, wind rose was plotted for mentioned months

(Fig. 3). As it can be seen in Fig. 3, in Tasuj sampling site prevailing wind blew from North East and South West during dry season; and in Ajabshir Township prevailing wind was from South to North and from

\section{The PM mass concentrations and relations}

Descriptive statistics of PM mass concentrations and the ratio of PMs' species in two sampling sites are presented in Table 2. According to Table 2, the average concentrations of TSP, $\mathrm{PM}_{10}, \mathrm{PM}_{2.5}$, and $\mathrm{PM}_{1}$ in Tasuj sampling site were $230.1 \pm 71.7,140.3 \pm 37.2,28.3 \pm 6.3$, and $23.0 \pm$
$5.6 \mu \mathrm{g} / \mathrm{m}^{3}$, respectively. In Ajabshir sampling site the average concentrations were $291.4 \pm 140.3,220.1 \pm 108.6$, $31.8 \pm 8.7$, and $27.4 \pm 7.6 \mu \mathrm{g} / \mathrm{m}^{3}$ for TSP, $\mathrm{PM}_{10}, \mathrm{PM}_{2.5}$, and $\mathrm{PM}_{1}$, respectively. In two sampling sites, the highest concentration of PM was observed during the summer season followed by spring.

Also, Table 2 represents the ratio of PMs' species in two sampling sites. The average of $\mathrm{PM}_{10}$ /TSP ratio in Ajabshir site (0.75) was higher than those for Tasuj site (0.64). Also the $\mathrm{PM}_{2.5} / \mathrm{PM}_{10}$ ratio for Ajabshir and Tasuj sampling sites ranged between 0.10-0.24 and $0.16-0.16$, respectively. There was no significance difference between PM's ratios obtained from Tasuj and Ajabshir sampling sites (Wilks' Lambda value = $0.73, \mathrm{~F}=0.65$ and Pvalue $=0.65$ ). Compared to our previous study on Tabriz urban and industrial suburban $\mathrm{PM}$ ratios, $\mathrm{PM}_{2.5} / \mathrm{PM}_{10}$ in Urmia lake region was smaller than urban (0.48) and industrial zone (0.38) of Tabriz [15]. It seems due to significant differences in particle sources and also some geographical and meteorological conditions the obtained results from one study could not be directly compared with the findings of other studies. 
Table 2 Descriptive statistics for 24- hour PM mass concentrations $\left(\mu \mathrm{g} / \mathrm{m}^{3}\right)$ and the ratio of PMs' species in Ajabshir and Tasuj sampling sites

\begin{tabular}{|c|c|c|c|c|c|c|c|c|c|}
\hline \multirow{2}{*}{$\begin{array}{l}\text { Sampling } \\
\text { sites }\end{array}$} & & \multicolumn{4}{|c|}{ PM concentrations $\left(\mu \mathrm{g} / \mathrm{m}^{3}\right)$} & \multicolumn{4}{|c|}{ The ratio of PMs' species } \\
\hline & & $\overline{\mathrm{TSP}}$ & $\mathrm{PM}_{10}$ & $\mathrm{PM}_{2.5}$ & $\mathrm{PM}_{1}$ & $\mathrm{PM}_{10} / \mathrm{TSP}$ & $\mathrm{PM}_{2.5} / \mathrm{PM}_{10}$ & $\mathrm{PM}_{1} / \mathrm{PM}_{10}$ & $\mathrm{PM}_{1}^{\prime} / \mathrm{PM}_{2.5}$ \\
\hline \multirow[t]{5}{*}{ Tasuj } & Min & 150.80 & 102.10 & 22.25 & 16.05 & 0.38 & 0.16 & 0.13 & 0.72 \\
\hline & Max & 338.80 & 194.80 & 36.50 & 29.46 & 0.90 & 0.26 & 0.21 & 0.89 \\
\hline & Average & 230.15 & 140.34 & 28.35 & 22.99 & 0.64 & 0.21 & 0.17 & 0.81 \\
\hline & SD & 71.74 & 37.17 & 6.27 & 5.64 & 0.19 & 0.04 & 0.03 & 0.06 \\
\hline & Median & 211.10 & 130.22 & 26.72 & 22.85 & 0.63 & 0.20 & 0.16 & 0.81 \\
\hline \multirow[t]{5}{*}{ Ajabshir } & Min & 168.19 & 95.94 & 22.50 & 18.60 & 0.57 & 0.10 & 0.10 & 0.80 \\
\hline & Max & 521.60 & 329.15 & 42.60 & 36.50 & 0.96 & 0.24 & 0.19 & 0.96 \\
\hline & Average & 291.36 & 220.08 & 31.84 & 27.45 & 0.75 & 0.17 & 0.14 & 0.86 \\
\hline & SD & 140.33 & 108.64 & 8.69 & 7.57 & 0.16 & 0.05 & 0.04 & 0.06 \\
\hline & Median & 261.57 & 230.00 & 30.55 & 28.05 & 0.74 & 0.16 & 0.13 & 0.86 \\
\hline
\end{tabular}

\section{Ionic composition of PM}

The statistical analysis of water soluble ions concentration in the TSP and $\mathrm{PM}_{10}$ showed that there was no significant difference between PM's ions concentrations at Tasuj and Ajabshir sites (Wilks' Lambda value = $0.022, F=4.35$ and Pvalue $=0.36$ for TSP and Wilks' Lambda value $=0.019 \quad \mathrm{~F}=5.1$ and Pvalue $=0.33$ for $\mathrm{PM}_{10}$ ). Therefore, the concentrations of water soluble ions were reported together as Urmia lake PM's ionic characterization.

The descriptive statistics of water-soluble ions concentration in TSP and $\mathrm{PM}_{10}$ collected from Urmia lake region are given in Table 3; expressed by cubic meter of sampled air (species in mass per volume units: $\mu \mathrm{g} / \mathrm{m}^{3}$ ) and by mg per $\mathrm{g}$ of sampled particles (species in mass/ mass units: $\mathrm{mg} / \mathrm{g}$ of TSP and $\mathrm{PM}_{10}$ ). Also, the average of water-soluble ions concentration in TSP and $\mathrm{PM}_{10}$ are presented in Fig. 4(a and b); expressed by cubic meter of sampled air $\left(\mu \mathrm{g} / \mathrm{m}^{3}\right)$ and percentage of species in the measured water soluble ions mass concentration.

The average of the total measured water-soluble ions in TSP was $28.75 \pm 12.9 \mu \mathrm{g} / \mathrm{m}^{3}(11.9 \pm 4.8 \%$ of total TSP mass) and in $\mathrm{PM}_{10}$ was $14.65 \pm 7.1 \mu \mathrm{g} / \mathrm{m}^{3}(8.7 \pm 4.4$ of total $\mathrm{PM}_{10}$ mass). As it can be seen in Fig. 4, about $90 \%$ of total detected water-soluble ions mass in $\mathrm{PM}_{10}$ included by $\mathrm{SO}_{4}^{2-}$ (29\%), $\mathrm{NO}_{3}^{-}$(21\%), $\mathrm{Na}+(14 \%), \mathrm{Cl}^{-}(13 \%)$, and $\mathrm{Ca}^{2+}(100 \%)$ in TSP, and $\mathrm{SO}_{4}^{2-}$ (29\%), $\mathrm{NO}_{3}^{-}$(20\%), $\mathrm{Na}$ ${ }^{+}(15 \%), \mathrm{Cl}^{-}(12 \%)$, and $\mathrm{Ca}^{2+}(12 \%)$. Among all detected ions, sulfate was the dominant constituent followed by nitrate and sodium. These results are in agreement with the study by Hassanzadeh et al. [16] which $\mathrm{Na}^{+}, \mathrm{K}^{+}, \mathrm{Ca}^{2}$ ${ }^{+}, \mathrm{Li}^{+}$, and $\mathrm{Mg}^{2+}$ were the main cations, while $\mathrm{Cl}^{-}, \mathrm{SO}_{4}^{2-}$, and $\mathrm{HCO}_{3}^{-}$were the main anions in Urmia lake's water. The Urmia lake is a hyper-saline lake and the concentrations of $\mathrm{Na}^{+}$and $\mathrm{Cl}^{-}$were roughly 4 times the concentration of natural seawater [16]. High concentrations of $\mathrm{Na}^{+}$and $\mathrm{Cl}^{-}$(especially for TSP) could be caused by the higher and persistent on-shore winds which create abundant sea water droplets and marine aerosols.

Our study show that the water soluble salts compose 3$20 \%$ of the total mass of TSP and $\mathrm{PM}_{10}$, while Abuduwaili et al. [3] stated that in the Ebinur region, the soluble salts compose $10-25 \%$ of the total mass of the saline dust, and salts are predominantly represented by sodium and calcium chlorides and sulfates. Gholampour et al. [15] reported that in the Tabriz urban and suburban region, that are the near to the Urmia lake, water soluble ions accounted for approximately $20 \pm 10 \%$ of total TSP mass and $25 \pm 12$ of total $\mathrm{PM}_{10}$ mass. Low percentage of total ions in the PM mass could be due to the small amount of secondary ion, especially non sea salt sulfate and ammonium, in the PM of Urmia lake bed.

Despite of higher PM and ions concentration during warm season, the comparison of mass percentage of water soluble ions in the ambient air PM of Urmia lake during cold and warm seasons showed that there was no significant difference between the mass percentage of PM's ions in the various seasons (Wilks' Lambda value = $0.4, F=1.64$ and Pvalue $=0.2$ ). Therefore, it could be concluded that in the Urmia lake region, the sources of PMs are same during various seasons.

\section{Size and morphology of aerosol particles}

SEM-EDX photographs for TSP and $\mathrm{PM}_{10}$ samples are shown as an example in Figs. 5(a) and 6(a); and the SEMEDX spectra of those are shown in Figs. 5(b) and 6 (b), respectively. Quantitative estimates of the particulate's (TSP sample) elemental composition are given in Table 4. As shown in the table; Oxygen (30.7\%) and Silicon (20.4\%) are the major component of the analyzed particulate. However, other elements, such as Iron (8.7\%), Magnesium (6.9\%), Calcium (6.6\%), Aluminum (4\%), Sodium (1.2\%), and Potassium (1\%) are also of great importance. Also, elemental composition quantitative estimates of the $\mathrm{PM}_{10}$ 
Table 3 Elemental analysis of Urmia lake TSP $\left(\mathrm{PM}_{10}\right)\left(\mu \mathrm{g} / \mathrm{m}^{3}\right.$ and $\left.\mathrm{mg} / \mathrm{g}\right)(n=48)$

\begin{tabular}{|c|c|c|c|c|c|c|c|c|c|c|}
\hline & \multicolumn{5}{|l|}{$\mu \mathrm{g} / \mathrm{m}^{3}$} & \multicolumn{5}{|l|}{$\mathrm{mg} / \mathrm{g}$} \\
\hline & Min & Max & Median & Mean & SD & Min & Max & Median & Mean & SD \\
\hline $\mathrm{Na}^{+}$ & $1.527(1.114)$ & $9.657(4.524)$ & $3.596(1.793)$ & $3.908(1.994)$ & $2.225(0.875)$ & $3.121(2.720)$ & $33.267(25.982)$ & $15.364(12.817)$ & $16.417(12.858)$ & $8.306(6.966)$ \\
\hline $\mathrm{NH}_{4}^{+}$ & $0.184(0.059)$ & $4.664(1.526)$ & $1.645(0.973)$ & $1.787(0.872)$ & $1.288(0.496)$ & $0.516(0.419)$ & $15.701(12.366)$ & $5.628(4.591)$ & 7.357 (5.333) & $4.701(3.856)$ \\
\hline $\mathrm{K}^{+}$ & $0.229(0.091)$ & $1.700(0.970)$ & $1.195(0.433)$ & $1.074(0.466)$ & $0.476(0.251)$ & $0.438(0.292)$ & $9.142(8.016)$ & 4.457 (2.503) & $4.753(3.120)$ & $2.563(2.232)$ \\
\hline $\mathrm{Mg}^{2+}$ & $0.164(0.094)$ & $0.567(0.267)$ & $0.237(0.157)$ & $0.270(0.166)$ & $0.117(0.052)$ & $0.379(0.339)$ & $1.572(1.645)$ & $1.189(1.077)$ & $1.130(1.021)$ & $0.403(0.432)$ \\
\hline $\mathrm{Ca}^{2+}$ & $1.822(1.204)$ & $4.769(3.540)$ & $2.687(2.044)$ & $2.763(2.090)$ & $0.842(0.688)$ & $5.533(3.300)$ & $22.560(20.125)$ & $12.349(12.828)$ & $12.006(12.738)$ & $5.068(5.048)$ \\
\hline $\mathrm{F}^{-}$ & $0.000(0.000)$ & $0.489(0.680)$ & $0.014(0.010)$ & $0.152(0.166)$ & $0.211(0.251)$ & $0.000(0.001)$ & $2.481(4.808)$ & $0.072(0.073)$ & $0.555(0.874)$ & $0.805(1.608)$ \\
\hline $\mathrm{Cl}^{-}$ & $2.227(1.220)$ & $5.506(4.267)$ & $3.307(1.425)$ & $3.553(1.876)$ & $1.223(0.929)$ & 4.350 (2.189) & $29.619(24.506)$ & $14.420(10.924)$ & $15.316(11.493)$ & $6.726(5.895)$ \\
\hline $\mathrm{NO}_{2}^{-}$ & $0.000(0.000)$ & $0.114(0.039)$ & $0.024(0.005)$ & $0.038(0.009)$ & $0.040(0.012)$ & $0.000(0.001)$ & $0.639(0.194)$ & $0.151(0.048)$ & $0.163(0.052)$ & $0.183(0.057)$ \\
\hline $\mathrm{NO}_{3}^{-}$ & $1.334(0.860)$ & $13.281(7.948)$ & $5.174(2.391)$ & 6.199 (2.814) & $4.251(2.131)$ & $5.800(5.012)$ & $62.317(45.650)$ & $27.651(10.547)$ & $25.539(16.632)$ & $16.400(13.801)$ \\
\hline $\mathrm{SO}_{4}^{2-}$ & $2.400(1.563)$ & $20.572(11.406)$ & $6.014(4.311)$ & $8.694(4.201)$ & $6.346(2.795)$ & $9.119(10.308)$ & 79.699 (65.508) & $36.516(18.353)$ & $34.815(23.182)$ & 21.675 (14.892) \\
\hline $\mathrm{PO}_{4}^{2-}$ & $0.000(0.000)$ & $0.830(0.031)$ & $0.184(0.000)$ & $0.316(0.003)$ & $0.332(0.009)$ & $0.001(0.001)$ & $3.839(0.216)$ & $0.923(0.002)$ & $1.250(0.020)$ & $1.361(0.062)$ \\
\hline Sum & 15.595 (8.479) & 49.267 (34.029) & $24.080(12.839)$ & $28.753(14.657)$ & $12.941(7.109)$ & $30.176(27.513)$ & $227.127(195.443)$ & $124.526(74.120)$ & $119.301(87.322)$ & $48.723(44.092)$ \\
\hline
\end{tabular}



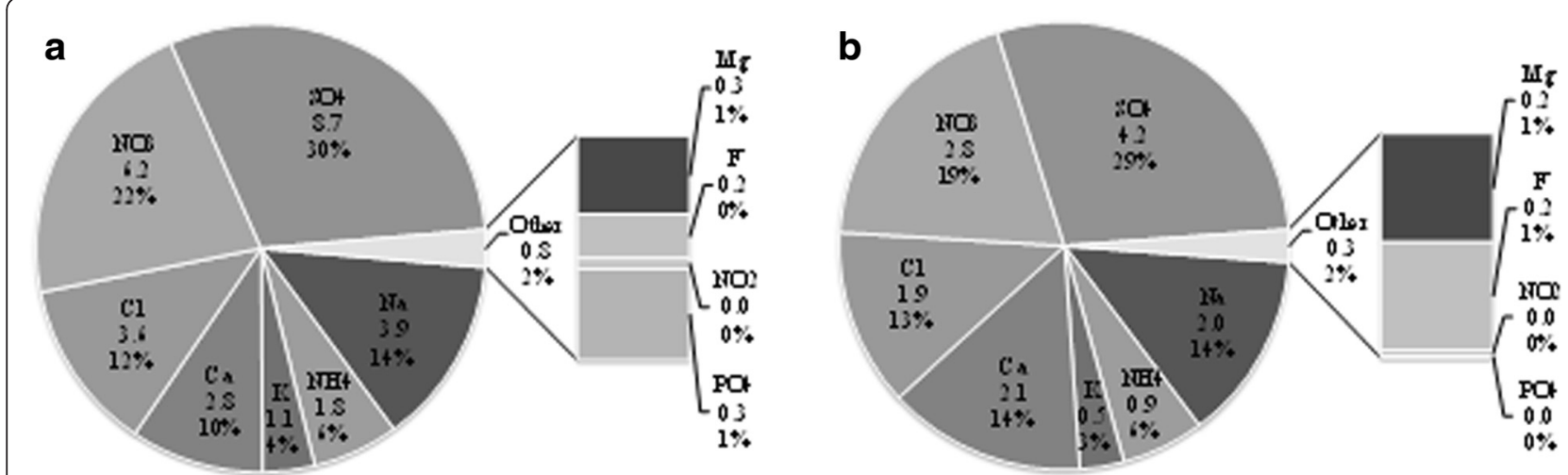

Fig. 4 Water-soluble ions concentration in TSP (a) and $\mathrm{PM}_{10}(\mathbf{b})$ collected from Urmia Lake

sample are given in Table 5. It can be seen that Oxygen (29.1\%) and Silicon (14.4\%) are the major component of the analyzed particulate. However, other elements, such as Aluminum (8\%), Zinc (7.1\%), Iron (6.7\%), Carbon (3.6\%), Magnesium (1.7\%), Chlorine (1.6\%), and Sodium (1.3) are with great importance.

Comparison of the TSP and $\mathrm{PM}_{10}$ elemental composition with world average values revealed that amount of Silicon in the Urmia lake dusts is less rich $(20.4 \%$ for TSP and $14.4 \%$ for $\mathrm{PM}_{10}$ vs. the world average of $59.9 \%$ ). However, the TSP resulted from Urmia lake dusts are richer in $\mathrm{Fe}(8.7 \%$ vs. the world average of $6.85 \%), \mathrm{Ca}$ ( $6.6 \%$ vs. the world average of $3.94 \%), \mathrm{Mg}(6.9 \%$ vs. the world average of $2.60 \%$ ), and sodium ( $1.2 \%$ vs. the world average of $0.5-1 \%$ ) than the Saharan, Harmattan, Chinese, and North American dusts [2].

It is important to note that the concentration of Chloride in the world average values is negligible; whereas our results indicated that chloride is one of the main ions in the Urmia lake dusts. This finding indicates that sea salt particles contribute large to the total mass of the particles collected. On the other hand, crustal dusts have also major role in the composition of TSP and $\mathrm{PM}_{10}$ in Urmia lake region.

\section{lonic balance of PM}

Often the ionic balance is employed to determine the potentially ions missing, which are not measured during the extraction and the detection. The plots of total cations versus the total anions equivalents $\left(n e q / \mathrm{m}^{3}\right)$ are presented in Fig. 7. The slope of the regression line for PM indicated a value greater than unity (slope $=2.95, \mathrm{R}^{2}=0.79$ for TSP and slope $=2.22, R^{2}=0.7$ for $\mathrm{PM}_{10}$ ), which might be due to high level of carbonate and bicarbonate, which were not analyzed. The main ions that could not be detected by our used method are $\mathrm{HCO}_{3}^{-}$and $\mathrm{H}^{+}$.
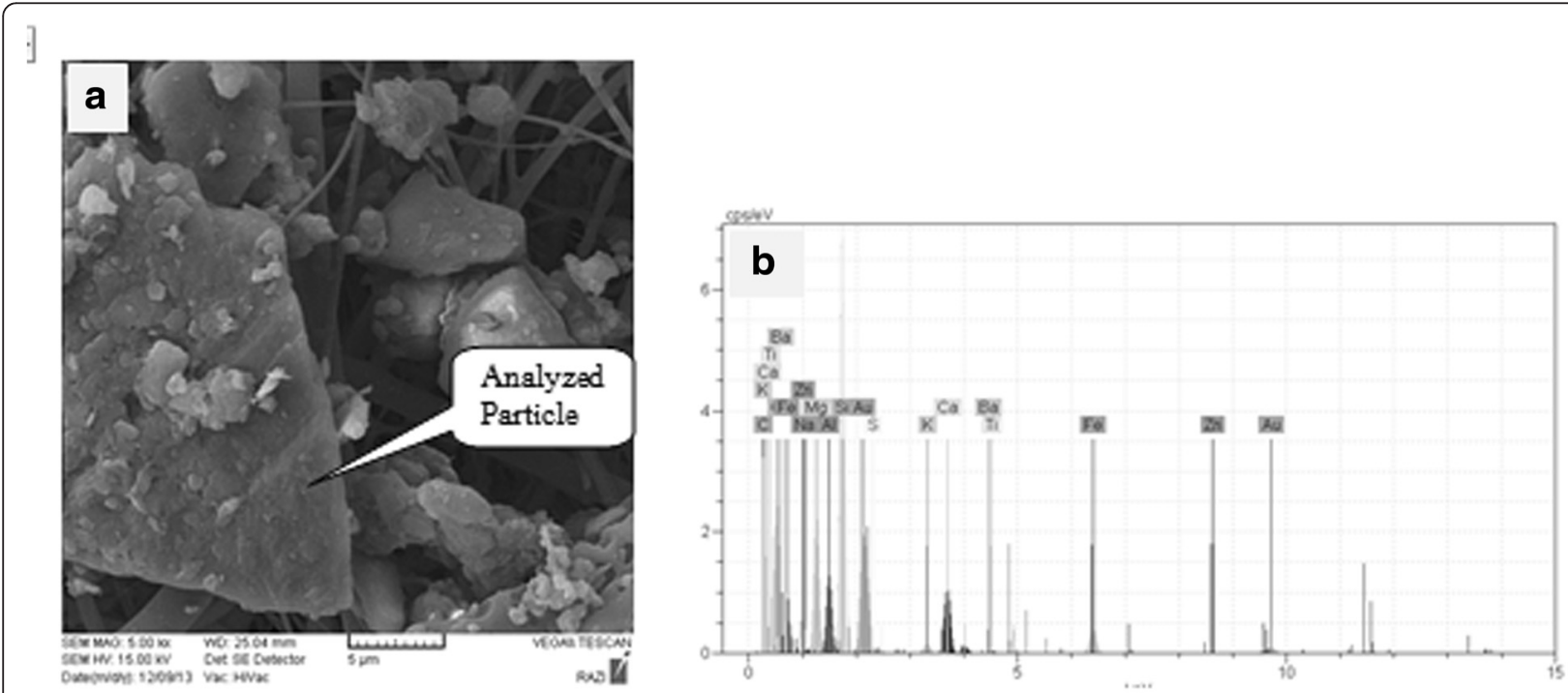

Fig. 5 SEM photograph (a) and X-ray spectra (b) of TSP sample 

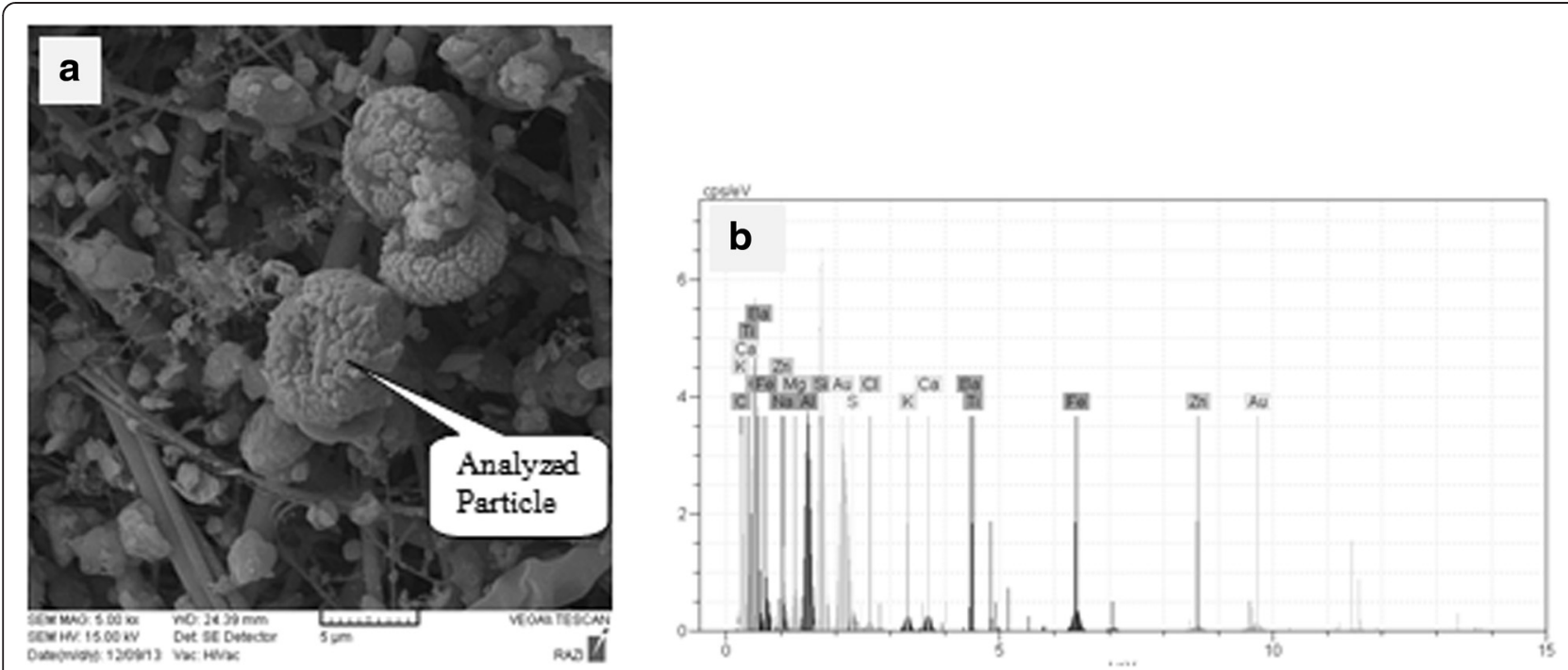

Fig. 6 SEM photograph (a) and X-ray spectra (b) of $\mathrm{PM}_{10}$ sample

On the other hand, as it was shown in Fig. 8, investigation of the relation between $\mathrm{Cl}^{-}$with $\mathrm{Na}^{+}$and $\mathrm{K}^{+}$revealed strong correlation between $\mathrm{Cl}^{-}$and $\mathrm{Na}^{+}\left(\mathrm{R}^{2}=0.91\right.$ and slope $=0.9$ for TSP and $R^{2}=0.76$ and slope $=0.8$ for $\mathrm{PM}_{10}$ ) and $\mathrm{Cl}^{-}$with $\mathrm{K}^{+}$. But, the slope of relation between $\mathrm{Cl}^{-}$with $\mathrm{K}^{+}$as smaller than $\mathrm{Na}^{+}$. These results allow us to conclude that the main chlorinated compound in PM was $\mathrm{NaCl}$ followed by $\mathrm{KCl}$.

\section{Ionic correlation of PM}

Ions correlation matrixes were calculated using bivariate correlations to quantify the relation between the elemental

Table 4 Quantitative estimates of elemental compositions of TSP sample

\begin{tabular}{lllll}
\hline Element & Series & unn. C [wt.-\%] & norm. C [wt.-\%] & Atom. C [at.-\%] \\
\hline Carbon & K series & 1.01 & 1.05 & 2.4 \\
Oxygen & K series & 29.46 & 30.72 & 52.68 \\
Sodium & K series & 1.21 & 1.22 & 1.27 \\
Magnesium & K series & 6.61 & 6.89 & 7.78 \\
Aluminium & K series & 3.83 & 3.99 & 4.06 \\
Silicon & K series & 19.59 & 20.43 & 19.96 \\
Sulfur & K series & 0.33 & 0.34 & 0.29 \\
Potassium & K series & 0.95 & 0.99 & 0.7 \\
Calcium & K series & 6.35 & 6.63 & 4.54 \\
Titanium & K series & 0.08 & 0.09 & 0.05 \\
Iron & K series & 8.37 & 8.73 & 4.29 \\
Zinc & K series & 0.76 & 0.79 & 0.33 \\
Barium & L series & 0.01 & 0.01 & 0 \\
Gold & M series & 18.33 & 19.11 & 2.66 \\
& Total: & $95.90 \%$ & & \\
\hline
\end{tabular}

concentrations. As it is shown in Table 6, the number of significant correlations of the elements in $\mathrm{PM}_{10}$ is higher and also stronger than the TSP elements. Yatkin et al. [17] has stated that values of elemental correlations in $\mathrm{PM}_{2.5}$ were much higher than $\mathrm{PM}_{10}$. Therefore, it could be concluded that with decreasing the size of PM, the elemental correlation increases and it might show that the sources of smaller PM were limited compared to larger ones.

High level of correlations was obtained between the terrestrial elements in TSP and $\mathrm{PM}_{10}$. For example, the correlation between $\mathrm{Ca}^{2+}$ and $\mathrm{Mg}^{2+}$ were 0.81 and 0.88 in TSP and $\mathrm{PM}_{10}$, respectively $(P<0.01)$. These results

Table 5 Quantitative estimates of elemental compositions of $\mathrm{PM}_{10}$ sample

\begin{tabular}{lllll}
\hline Element & Series & unn. C [wt.-\%] & norm. C [wt.-\%] & Atom. C [at.-\%] \\
\hline Carbon & K series & 3.87 & 3.58 & 8.46 \\
Oxygen & K series & 31.51 & 29.15 & 51.66 \\
Sodium & K series & 1.42 & 1.31 & 1.62 \\
Magnesium & K series & 1.86 & 1.72 & 2.01 \\
Aluminium & K series & 8.93 & 8.26 & 8.68 \\
Silicon & K series & 15.58 & 14.41 & 14.55 \\
Sulfur & K series & 1.06 & 0.98 & 0.86 \\
Chlorine & K series & 0.61 & 0.57 & 0.45 \\
Potassium & K series & 1.33 & 1.23 & 0.89 \\
Calcium & K series & 1.27 & 1.17 & 0.83 \\
Titanium & K series & 0.13 & 0.12 & 0.07 \\
Iron & K series & 7.27 & 6.72 & 3.41 \\
Zinc & K series & 7.71 & 7.14 & 3.09 \\
Barium & L series & 0.01 & 0.01 & 0 \\
& Total: & $108.10 \%$ & & \\
\hline
\end{tabular}




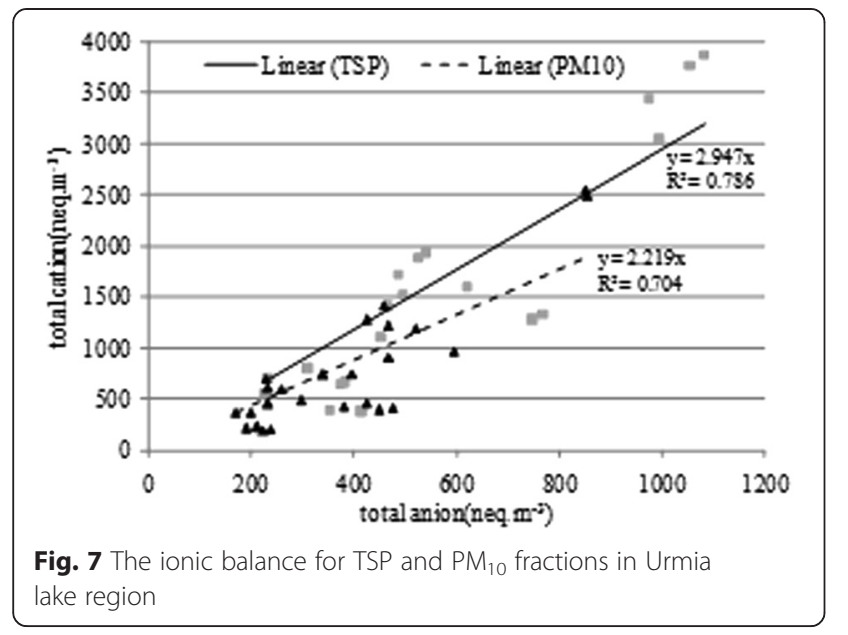

suggest that the sources of the terrestrial elements are most probably soil and soil-related activities. Also, the high and strong correlation between $\mathrm{Cl}^{-}, \mathrm{Na}^{+}, \mathrm{Ca}^{+}, \mathrm{Mg}^{2}$ ${ }^{+}$and $\mathrm{K}^{+}$indicates that a main part of PM was originated from marine salt. Correlations between $\mathrm{NH}_{4}^{+}$with $\mathrm{NO}_{3}^{-}$ and $\mathrm{SO}_{4}^{2-}$ were weak; 0.35 and 0.46 in TSP and 0.31 and 0.46 for $\mathrm{PM}_{10}$, respectively $(p>0.05)$. It could be concluded that secondary ions have a few roles in the formation of TSP and $\mathrm{PM}_{10}$ in the Urmia lake region.

The $\mathrm{Cl}^{-} / \mathrm{Na}^{+}$equivalent ratio for the whole study period ranged from 0.85 , in warm seasons, to 1.76 , in cold seasons, for TSP. This ratio for $\mathrm{PM}_{10}$ was 0.67 , in warm seasons, to 2.15 , in cold seasons. These results reveal that the loss of particulate $\mathrm{Cl}^{-}$during warm seasons caused by the formation of gaseous $\mathrm{HCl}$ from $\mathrm{NaCl}$ and acidic gases [18]. The chloride loss may be illustrated by the reaction between $\mathrm{HNO}_{3} /$ or $\mathrm{H}_{2} \mathrm{SO}_{4}$ and $\mathrm{NaCl}$ in seasalt particles generally formulated by:

$$
\mathrm{HNO}_{3}+\mathrm{NaCl}(\text { sea salt }) \rightarrow \mathrm{NaNO}_{3}(\text { sea salt })+\mathrm{HCl}
$$

The $\mathrm{Cl}^{-} / \mathrm{Na}$ + ratio in Urmia Lake region is broader and higher than the measured ratio in PM of urban and industrial zones of Tabriz (0.41-1.07 for TSP and 0.420.78 for $\mathrm{PM}_{10}$ ) [15].

\section{Principal components analysis of PM}

Three air quality principal components (PCs) for TSP and two PCs for $\mathrm{PM}_{10}$ with eigenvalues exceeding 1.0 were found. Based on Table 7, it was indicated that these PCs have a significant influence on the PM quality in Urmia Lake. For the TSP, the first PC showed high loading of $\mathrm{Na}^{+}, \mathrm{NH}_{4}^{+}, \mathrm{K}^{+}, \mathrm{Cl}^{-}, \mathrm{F}^{-}, \mathrm{NO}_{3}^{-}$, and $\mathrm{SO}_{4}^{2-}$ with a total variance of $57.6 \%$. These ions are saline particulates and formed from Urmia lake bed. The second PC showed the high loading of $\mathrm{Mg}^{2+}$ and $\mathrm{Ca}^{2+}$ with a total variance of $18.41 \%$. Theses ions are typically associated with crustal materials in windblown dust and the resuspended dust from around lands. FinallythehirdPChowedhighoading $\mathrm{NO}_{2}^{-}$and

$\mathrm{PO}_{4}^{2-}$ with a total variance of $13.08 \%$. Application of chemical fertilizer in agricultural lands around sampling sites could be the origin of third PC.

As mentioned above, two PCs were found for $\mathrm{PM}_{10}$. The first PC showed high loading of $\mathrm{Na}^{+}, \mathrm{K}^{+}, \mathrm{Mg}^{2+}, \mathrm{Ca}^{2}$ ${ }^{+}, \mathrm{Cl}^{-}, \mathrm{F}^{-}, \mathrm{NO}_{3}^{-}$, and $\mathrm{SO}_{4}^{2-}$ with a total variance of 59.9 $\%$. These ions typically associated with saline particulates and crustal materials in windblown dust and resuspended dust from Urmia lake bed and sampling sites around lands. The second PC showed high loading of $\mathrm{NH}_{4}^{+}, \mathrm{NO}_{2}^{-}$and $\mathrm{PO}_{4}^{2-}$ with a total variance of $17.1 \%$. High loading of these ions allows us to conclude that the main source of second PC was application of chemical fertilizer in agricultural lands around sampling sites.
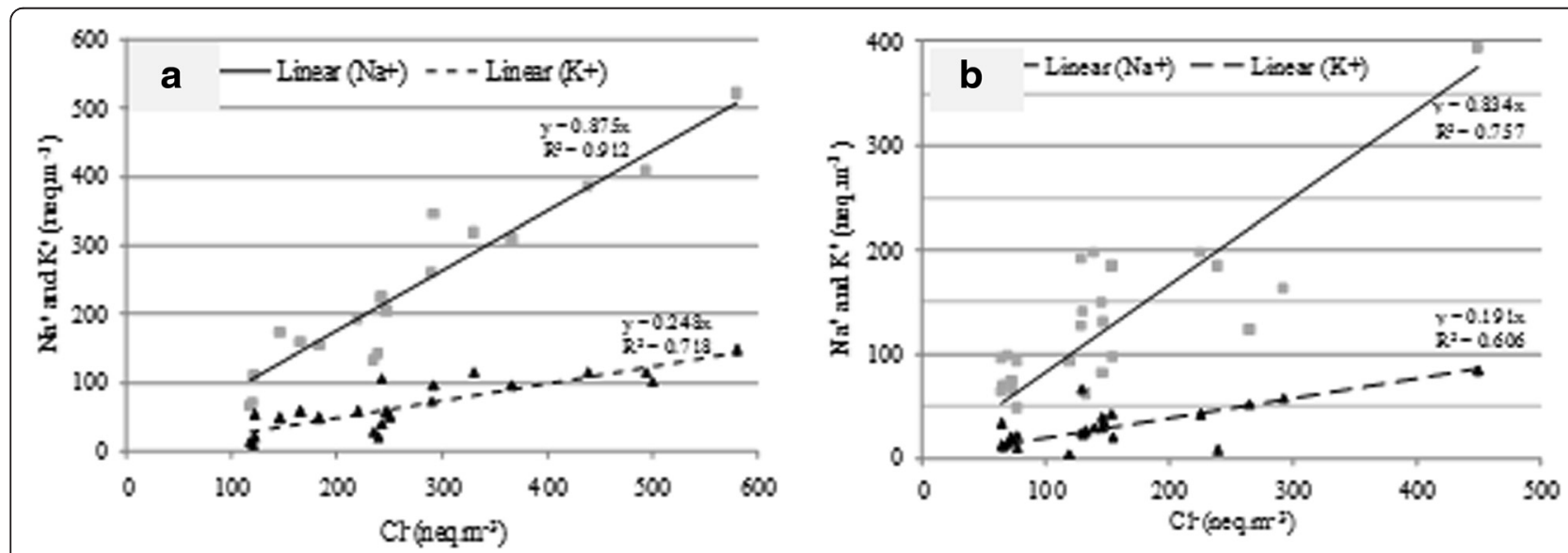

Fig. 8 Relation between $\mathrm{Cl}^{-}$with $\mathrm{Na}^{+}$and $\mathrm{K}^{+}$for (a) TSP and (b) $\mathrm{PM}_{10}$ fractions in Urmia lake region 
Table 6 The correlation matrixes of the elemental concentrations at urban site

\begin{tabular}{|c|c|c|c|c|c|c|c|c|c|c|}
\hline & $\mathrm{Na}^{+}$ & $\mathrm{NH}_{4}^{+}$ & $K^{+}$ & $\mathrm{Mg}^{2+}$ & $\mathrm{Ca}^{2+}$ & $F^{-}$ & $\mathrm{Cl}^{-}$ & $\mathrm{NO}_{2}^{-}$ & $\mathrm{NO}_{3}^{-}$ & $\mathrm{SO}_{4}^{2-}$ \\
\hline & TSP & & & & & & & & & \\
\hline $\mathrm{NH}_{4}^{+}$ & $0.593^{* *}$ & & & & & & & & & \\
\hline$K^{+}$ & $0.856^{* *}$ & $0.602^{* *}$ & & & & & & & & \\
\hline $\mathrm{Mg}^{2+}$ & $0.482^{*}$ & 0.368 & $0.464^{*}$ & & & & & & & \\
\hline $\mathrm{Ca}^{2+}$ & 0.344 & 0.014 & 0.363 & $0.806^{* *}$ & & & & & & \\
\hline$F^{-}$ & $0.657^{* *}$ & $0.658^{* *}$ & $0.487^{*}$ & 0.396 & 0.096 & & & & & \\
\hline $\mathrm{Cl}^{-}$ & $0.956^{* *}$ & $0.692^{* *}$ & $0.848^{* *}$ & $0.546^{* *}$ & 0.270 & $0.550^{* *}$ & & & & \\
\hline $\mathrm{NO}_{2}^{-}$ & 0.253 & $0.464^{*}$ & 0.178 & $0.600^{* *}$ & 0.407 & 0.397 & 0.256 & & & \\
\hline $\mathrm{NO}_{3}^{-}$ & $0.708^{* *}$ & 0.347 & $0.569^{* *}$ & $0.504^{*}$ & 0.301 & $0.925^{* *}$ & $0.576^{* *}$ & $0.406^{*}$ & & \\
\hline $\mathrm{SO}_{4}^{2-}$ & $0.704^{* *}$ & 0.457 & $0.547^{* *}$ & $0.432^{*}$ & 0.266 & $0.955^{* *}$ & $0.572^{* *}$ & $0.444^{*}$ & $0.958^{* *}$ & \\
\hline \multirow[t]{2}{*}{$\mathrm{PO}_{4}^{2-}$} & -0.053 & 0.194 & -0.167 & 0.239 & 0.388 & 0.334 & -0.090 & $0.485^{*}$ & $0.426^{*}$ & $0.503^{*}$ \\
\hline & $\mathrm{PM}_{10}$ & & & & & & & & & \\
\hline $\mathrm{NH}_{4}^{+}$ & $0.551^{* *}$ & & & & & & & & & \\
\hline$K^{+}$ & $0.749^{* *}$ & $0.454^{*}$ & & & & & & & & \\
\hline $\mathrm{Mg}^{2+}$ & $0.825^{* *}$ & $0.563^{* *}$ & $0.580^{* *}$ & & & & & & & \\
\hline $\mathrm{Ca}^{2+}$ & $0.625^{* *}$ & 0.257 & $0.441^{*}$ & $0.875^{* *}$ & & & & & & \\
\hline$F$ & $0.662^{* *}$ & 0.187 & $0.755^{* *}$ & $0.547^{* *}$ & $0.474^{*}$ & & & & & \\
\hline $\mathrm{Cl}^{-}$ & $0.882^{* *}$ & 0.392 & $0.795^{* *}$ & $0.814^{* *}$ & $0.753^{* *}$ & $0.834^{* *}$ & & & & \\
\hline $\mathrm{NO}_{2}^{-}$ & -0.087 & 0.345 & -0.180 & 0.062 & -0.120 & -0.169 & -0.293 & & & \\
\hline $\mathrm{NO}_{3}^{-}$ & $0.860^{* *}$ & 0.316 & $0.782^{* *}$ & $0.699^{* *}$ & $0.594^{* *}$ & $0.920^{* *}$ & $0.927^{* *}$ & -0.105 & & \\
\hline $\mathrm{SO}_{4}^{2-}$ & $0.868^{* *}$ & $0.464^{*}$ & $0.712^{* *}$ & $0.805^{* *}$ & $0.618^{* *}$ & $0.796^{* *}$ & $0.902^{* *}$ & 0.031 & $0.920^{* *}$ & \\
\hline $\mathrm{PO}_{4}^{2-}$ & -0.008 & -0.386 & 0.211 & 0.019 & 0.190 & $0.549^{* *}$ & 0.226 & -0.199 & 0.306 & 0.030 \\
\hline
\end{tabular}

${ }^{* *} P<0.01{ }^{*} P<0.05$

Bold numbers represented the significant correlation

Table 7 Varimax rotated PCA loadings for water-soluble ions of TSP and $\mathrm{PM}_{10}$ in Urmia Lake

\begin{tabular}{|c|c|c|c|c|c|}
\hline \multirow[t]{2}{*}{ Variables } & \multicolumn{3}{|l|}{ TSP } & \multicolumn{2}{|l|}{$\mathrm{PM}_{10}$} \\
\hline & PC1 & PC2 & PC3 & PC1 & PC2 \\
\hline $\mathrm{Na}+$ & 0.905 & 0.31 & -0.125 & 0.926 & 0.122 \\
\hline $\mathrm{NH}_{4}^{+}$ & 0.801 & -0.196 & 0.392 & 0.539 & 0.707 \\
\hline $\mathrm{K}^{+}$ & 0.881 & 0.34 & -0.184 & 0.824 & -0.121 \\
\hline $\mathrm{Mg}^{2+}$ & 0.36 & 0.803 & 0.335 & 0.879 & 0.217 \\
\hline $\mathrm{Ca}^{2+}$ & 0.056 & 0.952 & 0.197 & 0.743 & -0.047 \\
\hline $\mathrm{F}^{-}$ & 0.85 & -0.03 & 0.456 & 0.825 & -0.424 \\
\hline $\mathrm{Cl}^{-}$ & 0.913 & 0.246 & -0.094 & 0.967 & -0.171 \\
\hline $\mathrm{NO}_{2}^{-}$ & 0.195 & 0.302 & 0.777 & -0.082 & 0.63 \\
\hline $\mathrm{NO}_{3}^{-}$ & 0.806 & 0.191 & 0.473 & 0.934 & -0.204 \\
\hline $\mathrm{SO}_{4}^{2-}$ & 0.819 & 0.092 & 0.537 & 0.947 & 0.113 \\
\hline $\mathrm{PO}_{4}^{2-}$ & -0.064 & 0.172 & 0.897 & 0.167 & 0.808 \\
\hline Eigenvalue & 6.341 & 2.025 & 1.439 & 6.585 & 1.881 \\
\hline$\%$ of Variance & 57.648 & 18.41 & 13.085 & 59.861 & 17.097 \\
\hline$\%$ of Cumulative & 57.648 & 76.06 & 89.142 & 59.861 & 76.958 \\
\hline
\end{tabular}

Bold numbers represented the significant correlation

\section{Conclusion}

The implemented prevention and control measures are mainly the diversion or conservation of water to recover dried lake beds to reduce wind erosion. However, watersaving potential is limited due to continuing social and economical development in arid regions. On the other hand, evaporative losses from lake surfaces are high because of intense sunshine, large water areas, shallow water depths, and vigorous evaporation from the water surface.

As mentioned above, the water level of Urmia Lake has been decreased up to $6 \mathrm{~m}$ during last decade. Along with decreasing of water level, a salt desert is created with area more than $5000 \mathrm{~km}^{2}$. According to the dynamic characteristics of dust, grains with diameters smaller than $10 \mu \mathrm{m}$ can be transported by wind for several thousands of kilometers under common wind power conditions, and those with diameters of $10-20 \mu \mathrm{m}$ can be transported for hundreds or up to several thousands of kilometers with wind speeds $>15$ $\mathrm{m} / \mathrm{s}$. Therefore, at Urmia Lake region and especially during the warm season, wind could carry on saline dust to adjacent areas as far as hundreds of kilometers. 
The transported PM could damage agricultural lands, pollute the ecosystem and cause variety of disease in some state of Iran, Azerbaijan and other neighboring countries.

\section{Competing interests}

The authors declare that they have no competing interests.

\section{Authors' contributions}

All authors read and approved the final manuscript.

\section{Acknowledgments}

The authors would like to thank financial support for this research by Institute for Environmental Research (IER), Tehran University of Medical Sciences (grant number 92-01-46-21258). Also, we would like to acknowledge General Administration of Education at East Azarbayejan University of Medical Sciences for providing us with sampling locations.

\section{Author details}

${ }^{1}$ Center for Air Pollution Research, Institute for Environmental Research, Tehran University of Medical Sciences, Tehran, Iran. ${ }^{2}$ School of Public Health, Tabriz University of Medical Sciences, Tabriz, Iran. ${ }^{3}$ School of Public Health, Tehran University of Medical Sciences, Tehran, Iran. ${ }^{4}$ Center for Solid Waste Research, Institute for Environmental Research, Tehran University of Medical Sciences, Tehran, Iran. ${ }^{5}$ National Institute of Health Research, Tehran University of Medical Sciences, Tehran, Iran.

Received: 26 October 2014 Accepted: 14 November 2015 Published online: 28 November 2015

\section{References}

1. Okin GS, Mahowald N, Chadwick OA, Artaxo P. Impact of desert dust on the biogeochemistry of phosphorus in terrestrial ecosystems. Global Biogeochemical Cycles. 2004;18(2).

2. Goudie AS, Middleton NJ. Desert dust in the global system. Springer; 2006

3. Abuduwaili J, Liu D, Wu G. Saline dust storms and their ecological impacts in arid regions. J Arid Land. 2010;2(2):144-50.

4. Micklin P. The Aral sea disaster. Annu Rev Earth Planet Sci. 2007;35:47-72.

5. Gill TE. Eolian sediments generated by anthropogenic disturbance of playas: human impacts on the geomorphic system and geomorphic impacts on the human system. Geomorphology. 1996;17(1):207-28.

6. Small I, Van der Meer J, Upshur R. Acting on an environmental health disaster: the case of the Aral Sea. Environ Health Perspect. 2001;109(6):547.

7. $\mathrm{Mu} G$, Yan $\mathrm{S}$, Jilil A, He Q, Xai X. Wind erosion at the dry-up bottom of Aiby Lake. Sci China Ser D Earth Sci. 2002;45(1):157-64.

8. Liu D, Abuduwaili J, Lei J, Wu G. Deposition rate and chemical composition of the Aeolian dust from a bare saline playa, Ebinur Lake, Xinjiang, China. Water Air Soil Pollut. 2011;218(1-4):175-84.

9. Hoseinpour M, Fakheri Fard A, Naghili R, editors. Death Of Urmia Lake, a Silent Disaster Investigating Causes, Results and Solutions of Urmia Lake drying. 1st International Applied Geological Congress, Department of Geology, Islamic Azad University, Islamic Azad University-Mashad Branch Iran; 2010.

10. Eimanifar A, Mohebbi F. Urmia Lake (northwest Iran): a brief review. Saline Systems. 2007;3(5):1-8.

11. Cheng M-T, Chou W-C, Chio C-P, Hsu S-C, Su Y-R, Kuo P-H, et al. Compositions and source apportionments of atmospheric aerosol during Asian dust storm and local pollution in central Taiwan. J Atmos Chem. 2008; 61(2):155-73.

12. NCDC. 2013. http://www7.ncdc.noaa.gov/CDO/cdoselect.cmd.

13. Fu P, Huang J, Li C, Zhong S. The properties of dust aerosol and reducing tendency of the dust storms in northwest China. Atmos Environ. 2008; 42(23):5896-904

14. Ta W, Dong Z, Sanzhi C. Effect of the 1950s large-scale migration for land reclamation on spring dust storms in Northwest China. Atmos Environ. 2006;40(30):5815-23.

15. Gholampour A, Nabizadeh R, Naseri S, Yunesian M, Taghipour H, Rastkari N, et al. Exposure and health impacts of outdoor particulate matter in two urban and industrialized area of Tabriz, Iran. J Environ Health Sci Eng. 2014; 12(1):27.

16. Hassanzadeh E, Zarghami M, Hassanzadeh Y. Determining the main factors in declining the Urmia Lake level by using system dynamics modeling. Water Resour Manag. 2012;26(1):129-45.

17. Yatkin S, Bayram A. Elemental composition and sources of particulate matter in the ambient air of a Metropolitan City. Atmos Res. 2007;85(1):126-39.

18. Galindo N, Yubero E, Nicolas JF, Crespo J. Water-soluble ions measured in fine particulate matter next to cement works. Atmos Environ. 2011;45(12): 2043-9.

\section{Submit your next manuscript to BioMed Central} and we will help you at every step:

- We accept pre-submission inquiries

- Our selector tool helps you to find the most relevant journal

- We provide round the clock customer support

- Convenient online submission

- Thorough peer review

- Inclusion in PubMed and all major indexing services

- Maximum visibility for your research

Submit your manuscript at www.biomedcentral.com/submit 